\title{
Pre-Service Social Studies Teachers' Views About Teacher Training (Focus Group Interviews)
}

\author{
Selçuk İlgaz \\ Correspondence: Selçuk Ilgaz, Education Faculty, Ataturk University, Erzurum, Turkey.
}

Received: February 28, 2019

doi:10.11114/jets.v7i4.4107

\author{
Accepted: March 18, 2019 \\ Online Published: March 19, 2019 \\ URL: https://doi.org/10.11114/jets.v7i4.4107
}

\begin{abstract}
The purpose of this study is to reveal the pre-service social studies teachers' opinions about teacher training. This study is carried out via qualitative research method. The study group consisted of 64 th year students studying in the department of social studies teaching in Kazım Karabekir Education Faculty of Ataturk University in 2018-2019 academic year. The data obtained with focus group interview technique was analysed via content analysis.

Considering the results, the pre-service teachers argued that the purposes of the education faculties were to graduate students or only tell subjects based on memorization. According to the pre-service teachers, education faculties generally fail in teacher training. They stated that only existing applied courses would make contributions to their professional experience. In addition to this, they mentioned focusing more attention on practices and stated that the training practices should be increased. They determined that the courses in social studies program should be redesigned according to their functionality.
\end{abstract}

Keywords: pre-service social studies teachers, teacher training, education faculty

\section{Introduction}

Throughout the history, all societies have felt the need of qualified people. This need sometimes manifested itself in the military field, sometimes in religious field, and sometimes in social life. The countries tried to fulfil their need of qualified people with the educational institutions they established. For this, every society created an education system which was remoulded with their culture (Ilkay, 2016, p. 144). One of these societies is the Turkish society which has the oldest and deep-rooted culture.

Turkish people introduced an understanding of education according to their own living styles to meet their needs for qualified people. One of the most important factors of this educational understanding is customs (Doğan, 2010, p.47-48). In other words, Turkish people used the customs as an educational tool so that their children and teenagers at school age could socialize and become a qualified person (Akyüz, 2001, p. 5). This situation was observed in the Turkish states that existed before the Islam and also in the Turkish states that were founded after the Islam. The Huns, the Gokturks, the Uighurs, the Karakhanids, the Seljuks, and the Ottomans were the Turkish states which put customs at forefront in their educational understanding.

With the Turks acceptance of Islam, the "madrasa" emerged to become the first planned, regular, and strong formal educational institution (Boy, 2017, p. 58). The madrasa which was founded under the influence of the customs and the newly accepted religion made a breakthrough in terms of education and spread to everywhere. After the Seljuks who shaped the education and training with Nizamiye madrassas (Akyüz, 2001, p. 42), the Ottoman state developed the madrasa system according to its age and used the madrassas to train the type of people it needed. Till the middle of the $18^{\text {th }}$ century, the clergy performed the education and training in the madrassas as in Christianity (Öztürk, 2007, p. XI). These clergies who were called mudarris were required to continue their education until they graduated from the madrassa called "sahn" to take office. After their graduation, the candidates who were ratified firstly completed their education near a mudarris and then they were appointed in place of the retired mudarisses (Binbaşığlu, 2009, p. 68). In addition to this, Mehmed the Conqueror (Fatih Sultan Mehmed) foresaw a system for elementary school teachers different from the general madrassa system. According to this system which could be considered as the first step taken in the field of teacher training in Turkish education history, two courses which mean "discussion rules" and "teaching methods" were included in the training program of the mudarris candidates and fiqh (or Islamic jurisprudence) was excluded from the program (Akyüz, 2001, p. 83). However, in the $18^{\text {th }}$ century, corruption began in the madrassa system 
like in the other institutions in the Ottoman Empire (Sakaoğlu, 2003, p. 55). Thus, the first teacher education school called "Darülmuallimin-i Rüşdi" was opened on March 18, 1848 in the Ottoman Empire that tried to change and develop the education system in struggle for westernization (Öztürk, 2007, p. 4).

The innovation movements which began especially with the Constitutional Monarchy II about the teacher education continued with the foundation of the Republic (Ergün, 1982, p. 32-33). Many studies were carried out about pre-school teaching (Primary Teaching School), elementary school teaching, village teaching, and vocational and technical education teaching during the period when the foundations of present teacher training system were laid. However, it was understood that most of the studies carried out during Ataturk's period focused on elementary school teaching (Öztürk, 2007, p. 233).

As a result of the changes and developments that continued after Ataturk's era, teacher education schools were first converted to educational institutions and then to education faculties. With the entry of legislative decree numbered 41 and dated July 1982 into force, the education faculties were included in Turkish education system as a new phenomenon. However, the emergence of a new phenomenon as an education faculty could not solve the problems about teacher training. Thus, besides the redesign of the content of the programs in education faculties, there was a need for the addition of new programs. One of these new programs was social studies teaching.

\subsection{Social Studies Education}

One of the most important purposes of education all over the world is to train good citizens. For this, some countries by using the disciplines of history, geography, or civics and some other countries by using the other disciplines of social sciences in addition to these three disciplines try to train a good citizen.

Beginning with the $19^{\text {th }}$ century, the increase in the number of multi-cultural societies has brought along the problems of citizenship. The countries that sought for solutions for these used the education as a tool for training a good citizen. The United States of America, one of the countries that encountered this problem prepared a program that included subjects like history, geography, citizenship and social issues and their solutions with the intention of creating a national society in the National Education Association that gathered in 1892 (Bilgili, 2013, p. 23; Tay, 2011). The concept of "social studies" first emerged in this meeting.

In our country, a new course called "social studies" was formed for the $4^{\text {th }}$ and $5^{\text {th }}$ grades with the integration of history, geography, and civics in 1968. In 1998-1999 education year, a new program called social studies education was opened in all education faculties and it was up-dated according to the 8-year compulsory education in 1997 (Öcal \& Yakar, 2015, p. 309). Considering this, a new program based on constructivist approach in 2004 started and it was foreseen that the teacher would play the role of a guide (Safran, 2011, p. 13; Öztürk, 2009, p. 27). Within the context of the new program mentioned, the content of the social studies education in education faculties changed. In this context, beginning in 2006, the education faculties started to train teachers according the new curriculum based on constructivist approach (Kaymakçı, 2012, p. 42). In 2018, within the context of the "New Undergraduate Teacher Training Program", the course names and content of the social studies education were updated (Council of Higher Education). In order to study social studies teaching in Turkey, it is required that students must get the necessary scores from a centralized examination and take a four-year education.

Teachers are the people who construct the societies considering the features of the era. It is required that teachers who are going to guide the individuals who will construct the societies must be well-equipped before starting their profession (Kılıç \& Saruhan, 2006, p. 408). Depending on the rapidly growing science and technology, the same changes and developments have been experienced about the issue of teacher training. Many educators carry out studies related to the problems experienced about teacher training and suggestions for solutions for example, Tarman and Adalar (2016) compared the social studies education curricula in the USA and Turkey and concluded that the curriculum in Turkey must be improved. Beldağ and Yaylacı (2014) in their study determined that the pre-service teachers' applied courses were quite effective in terms of introduction to teaching, communication with students and developing class management skills, and applying institutional knowledge. Tonga (2012) stated that the terms of the "School Experience" and "Teaching Practice" must be increased, Kaymakçı (2012) asserted that the program and the content must be revised after examining the social studies course programs between 1998 and 2006, and Akhan (2015) revealed that the pre-service teachers had positive attitudes towards the program. The purpose of this study is to reveal the pre-service social studies teachers' opinions about teacher training. The student opinions about the following issues were determined:

1- Education faculties' purposes of training teachers

2- Whether or not the education faculties are successful in teacher training

3- The effectiveness of the courses taken on the teaching profession

4- The qualities of being a good social studies teacher

5- Suggestions for the required teacher training 


\section{Method}

\subsection{The Research Model}

This study is carried out via qualitative research method. Qualitative research is defined as a research method that is used to gain understanding of perceptions and phenomena in a natural setting and in a realistic and holistic way (Şimşek \& Y1ldırım, 2013, p. 39). Case study model was used in the study. Case study is an in-depth study of particular situation, without intervening the events and asking questions like how and why (Akar, 2016, p. 113)

\subsection{The Study Group}

The study group consisted of six $4^{\text {th }}$ year students studying in the department of social studies teaching in Kazım Karabekir Education Faculty of Ataturk University in 2018-2019 academic year. Convenience sampling was used to select the subjects (Şimşek \& Yıldırım, 2013, p. 141). Four female and two male students volunteered to participate in the study.

\subsection{Data Collection}

Focus group interview technique was used in the study to reveal the participants' views. The purpose of the focus group interviews is to gain in-depth and multi-dimensional quantitative data from the participants about their feelings, thoughts, experiences, attitudes, and perceptions about a particular topic (Dilshad \& Latif, 2013; Bowling, 2002). In the study, firstly the focus group interview was planned and then the implementation was carried out. After that, the data were recorded and analysed (Çokluk, Yılmaz \& Oğuz, 2011). Semi-structured interview forms were developed as a data collection tool of focus group interview. While preparing this form, the expert opinions were taken and the questions' reliability and validity were tested.

Within the planning of the study, piloting was carried out with a different group of 6 people. Then, the interview form consisting of five questions was implemented with the participants via focus group interview technique. The author of the study led the focus group interviews as the leader and a chat environment was created. The interview was recorded with the participants' consent.

\subsection{Data Analysis}

The data obtained with focus group interview technique was analysed via content analysis. The interview data which was audio recorded was firstly transcribed and then the categories were generated after analysing the participants' opinions individually. The results obtained were tabulated and explained.

\section{Results}

\subsection{Students' Views Regarding the Education Faculties' Purposes of Training Teachers}

Considering the question about the education faculties' purpose of training teachers, six students responded positively and six students responded negatively. The students' views regarding the education faculties' purposes of training teachers were presented in Table 1 .

Table 1. Students' views regarding the education faculties' purposes of training teachers

\begin{tabular}{ll}
\hline & $\mathrm{f}$ \\
\hline Negative Opinions & 3 \\
To graduate students & 3 \\
Education based on memorization & \\
Positive Opinions & 2 \\
To train individuals who love human beings & 2 \\
To train well-equipped teachers in every field & 1 \\
To train broad minded people & 1 \\
To train unselfish teachers & \\
\hline
\end{tabular}

As a result of the interviews carried out with the students, it is found that there are negative opinions about the education faculties' purposes of training teachers. Three students having negative opinions about the subject stated that the purpose of the education faculties was only to graduate students. For example, one student said, "To me, another thing is they intend to graduate students, they think that let's graduate them, no matter what this student does, that is we are left to our fate (S1). S3 similarly defended the following opinion, "To me, while training teachers, neither our faculty nor the other faculties have a positive side, that is, let us train a university student, no matter whether he is 
appointed or not, their purpose is not to train teachers. A student who argued that their purpose was only to train students graduated from the faculty said, "The purpose is to train faculty graduates, we are made to graduate to increase the education level" (S6) and defended that the purpose of education faculties were to graduate students and increase the education level.

The shared opinion of the three students with negative opinions is that students were exposed to memorization for learning the subjects. The following are the student opinions about this issue:

"In one night I sat and memorized the whole world map. My memory is very strong but now I don't remember any of them because I memorized them. This is what I see in our faculty" (S6)

"Except for the applied courses, in the other field courses, the teacher makes use memorize the subject and then leave. S/he does not tell us how to explain it. But, of course this is mutual." (S1)

"Now we are all taking practical training. Nobody can apply the knowledge learned at school. When I went on a training, I did not learn anything at school, they only tried to make me memorize geography and history." (S3)

In addition to such negative opinions, the students presented some positive opinions. However, these opinions included what the education faculties required to have. For example, two participants said that the purpose of the education faculties were to train individuals who love people. Another two participants stated that the purpose was to train well-equipped teachers in every field. The participants' opinions were presented below:

“To train a person who loves people, mostly children." (S3)

"I don't believe that a person who does not love human beings can become a teacher" (S1)

"When talking about training teachers, a person who is well-equipped in any field comes to my mind” (S6)

"Considering the present generation, they are disrespectful, they do not care anything. We must be well-educated in order to prevent this, that is, we must be well-equipped" (S2)

One participant said that the purpose was to train broad-minded people and another stated that the purpose was to train unselfish teachers:

"Sir, what comes to my mind is broad-minded people. When thinking about teacher training, what comes to my mind is the teacher who not only thinks of teaching the course but also who considers winning the students over." (S5)

"One thing is he must not be selfish. He must be someone who is to share more than everything he has with other people" (S6)

Three students participating in the interview responded both negative and positive opinions. These participants determined that the education faculties did not succeed in realizing their purposes; however, they remarked that this was also due to them. Moreover, they said that there was not any problem while transferring knowledge to the students but they had problems while they were transferring what they have learnt. The participants' opinions were presented below:

"To me, education faculties fail to train teachers but I can't say absolutely. In my opinion, students also make mistakes. There is no meaning to put the blame on others. The person must first blame himself. Primarily, we are in this department without knowing what we want, so we are to blame ourselves. (S1)

"There is no problem while transferring knowledge to us. For example, after I practised what I learnt in special teaching course, I stopped the video during the training because students were not listening to the course. Suddenly all of them turned their focus on me, even during the break they came to me and said that they were not bored and asked me whether or not I was going to ask questions. That is, there is no problem in transferring information but except for few courses nobody told us how to teach when we became a teacher. There is only knowledge." (S5)

"To me, you teach us the topic but you don't teach us how to teach the subjects. (S6)

3.2 Students' Views Regarding Whether or Not Education Faculties Are Successful in Teacher Training

The responses of the pre-service teachers about the question were grouped into three categories. These are lack of training, focusing attention more on theoretical education, and lack of students' individual efforts. These three categories were presented in Table -2 .

Table 2. Do education faculties succeed in teacher training?

\begin{tabular}{ll}
\hline Opinions & $\mathrm{f}$ \\
\hline Lack of apprenticeship & 4 \\
Focusing attention on theoretical education & 3 \\
Lack of students' individual efforts & 2 \\
\hline
\end{tabular}


The responses of the participants to the question "Do education faculties succeed in teacher training?" are that they are generally unsuccessful. The students who participated in the interviews stated that focusing attention more on theoretical education or lack of applied courses caused failure. For example, one of the participants said that except for two or three courses, knowledge was only transferred and they could not learn how to teach this knowledge.

"But there is something. Except for the knowledge taught by two or three teachers in the course, none of the teachers tell us that this is the way you are going to teach the subject that I have told you. They only teach the topic in the book and then leave" (S6). Similar views were also shared by another participant. ". Apart from material development course, values education course, or special teaching methods course, the teacher tells the other common field courses and then leaves. Even we are made to memorize them by the teacher. There is no explanation about how we will teach them. But of course, this is mutual (S1). Another participant determined that he understood the lack of practice in the faculty when he went on a training and shared his opinions.

"Right now, we are all taking training but nobody can apply what he has learnt at school. When I go on training, I tell myself that I have not learnt anything at school. They only made me memorize geography or history. Personally, it looks as if I have not learnt anything about teaching for four years." S3

Considering "School experience" and "Teaching Practice", most of the students complained about incompetency. The opinions about this issue were given below:

"They don't take care of us during the training, they even do not ask what we did during the training." (S5)

"We take practical training in our final year of studies. The training seems negative to me because we go there and listen to the lesson like a trinket. They ask us to write a report, then they download the report from the net and then bring it. They neither tell a lesson or do something. To me, neither our faculty nor the other education faculties know anything about teacher training" (S3)

"If the training had been given in the second year of our studies, I could have learnt more things because we would observe our internship teachers, take them as a role model, and see their mistakes and would not make them" (S1)

"What I want to say is that the training may begin in the first grade or it must certainly begin in the second grade" (S4)

The opinions which attribute the failure of education faculties in teacher training to students or students' incompetency are given below:

"Sir, education faculties are unsuccessful but there is no meaning to put the blame on one side. For example, we start studying for the exam five days before the exams. To me, we memorize them just to save the day." (S4)

"In my opinion, education faculties are unsuccessful in teacher training but I can't say certainly. To me, students are also responsible for their faults. A person must also blame oneself. Firstly, we chose this department without knowing what we wanted, that is, we are also faulty. " (S1)

\subsection{Students' Views Regarding Whether or Not Courses Taken at Education Faculties Are Effective in Teaching Profession}

The responses of the participants to the question about whether or not courses taken at education faculties are effective in teaching profession were examined under four categories: general problems in education and examination system, good lecturing performance of the academic staffs, lack of applications, and gaining professional experiences from the applied courses. The pre-service teachers' reason for this issue was given in Table-3.

Table 3. Students' views regarding whether or not courses taken at education faculties are effective in teaching profession

\begin{tabular}{ll}
\hline Negative Opinions & $\mathrm{f}$ \\
\hline General problems in education and examination system & 4 \\
Lack of practice & 2 \\
Positive opinions & \\
Good lecturing of academic staff & 3 \\
Gaining professional experience with applied courses & 2 \\
\hline
\end{tabular}

Considering the participant views about the subject, two participants' views were positive but two other views were negative. Four students argued that due to the problems in education and examination system, the courses taken would not be effective in their professional life. In addition, two students stated that due to the lack of implementations, the courses taken would not be effective in their professional life. The negative opinions of the participants were given below: 
Considering the problems in education and examination system, students stated that due to generally multiple choice questions, they could not develop their thinking and interpretation skills and thus, most of the courses would not be effective in their teaching profession.

"For example, a person who becomes a teacher must express oneself. Moreover, he must express oneself to others. You can have the knowledge but the important thing is that can you transfer this knowledge to the others? For example, in our faculty because exams are mostly tests, we only memorize the subjects. Maybe, my peers won't agree with me but I always prefer traditional written exams because one of our teachers told us that he would give a traditional exam. We were all scared. We all think that the teacher will give us a written test but can we write it? or have we forgotten writing? When this is the case, we think that whether I can express myself on the paper and what I will write? That's why the exams must be traditional written ones but not the multiple choice ones so that we can develop our thinking skills and interpretation skills." (S4)

Another participant used a similar statement to support these views: "Sir, teachers think that they do students a favour by giving them tests but we are students and we look after our own interests so want it to be like this. In fact, teachers should not listen to their students" (S1).

The students did not only mention the exams in their university life with the examination system. In addition, they mentioned the examinations taken for the teacher selection. They argued that the courses they took in their educational life were intended for Public Personal Selection Examination (KPSS) but not for teaching profession.

"The people studying for KPSS say that I do the exam quietly and the important thing is how to solve the question. Then, I must learn the ways of solution of the problem. This situation does not work in teaching profession if you cannot explain it." S4

The students defend that KPSS must be changed so the examination can assess whether or not a person can work as a teacher and thus they think that the courses they take during their educational life will be more effective.

"Sir, it is not important to remove the exam. You will ask the student to tell the Treaty of Lausanne, explain one of the courses in pedagogical formation or implement six hats or fish skeleton. Does this man use the technique correctly, how does he use the technical language, can he become a teacher when he tells the history subjects? An interview should not last more than 2 minutes. If a teacher is chosen, it must last at least an hour. If this method is realized, I can tell myselffor four years that I will sit for such an exam in the interview. I wonder whether or not they will ask me to tell geography. Or will they ask me questions from history or education? If I know what to do, I can study, accordingly and I will achieve this competence. Then, I can constantly think how to deliver a lecture in front of the jury for four years. (S4)

"When a person who is not qualified to be a teacher gets a good score in KPSS, he becomes a teacher. Is it reasonable? Teaching is a humanistic profession, it really is, you cannot become a teacher when you get 85 ." (S1)

In addition to this, the students stated that the admission examinations for education faculties should change. The opinions about this subject are given below:

"The elimination must be carried out while being admitted to the university. Accept 50 students instead of accepting one million students." (S6)

"Sir, there is something. They admit students to the faculty of medicine, don't they? That is, they deal with human life. If we think, we also deal with human life. In other words, they force them. They get 500 points when they are admitted. It must be the same for teaching. As a result, they will train people and our future will be in their hands. As a result, if a doctor's mistake kills a patient, a teacher's mistake can kill a generation." S1

The other negative opinions about the ineffectiveness of the courses in teaching profession are related to the lack of applications. The students' views about this subject are given below:

"Of course, the knowledge we are taught is valuable but we have problems about transferring the knowledge. It is like I know English but I can't speak." S1

"We have been on a driving course; we have learnt everything theoretically but we cannot drive because we have never driven." (S6)

"Yes, of course knowledge is important but I could not tell the subject we were told in the week during the training. Maybe it is because of me but I could not teach it to the students" (S5)

In addition to such negative opinions, there were also positive opinions about the courses taken. Three students stated that their lecturers at university taught the subjects very well and two students said that they gained experience thanks to applied courses. The students' views about the lecturing of the academic staff were given below:

"I have to memorize in some courses to learn. Sometimes although I don't have a course, I attend some lecturers' 
courses because I say that this lecturer teaches very well. It will retain in my mind. In the future, I will teach these to my students when I will become a teacher." (S4)

"But I don't say that the teachers cannot tell the subjects very well. They tell very well but we cannot transfer them. (S6)

"Sir, the knowledge given is valuable, in other words, all we learn is very important. We haven't studied a lot but they have taught very important information. We cannot deny it." (S1)

The students' views which argue that they gained experience were presented below:

"Special teaching methods course is the only course that will really benefit me because I acted like a teacher in the class and our teacher told what we could do and couldn't do. They said that we would memorize in the other courses. The important thing here is to know how to teach and how to become a teacher. Thus, the courses that I need most are the training and special teaching methods courses because I learn by doing." (S3)

"We practised school trip and observation methods last year. I still remember them. I can tell you all of them, even I can explain much better because they retained in my mind. I thought how to tell them. I really gained a wonderful experience for my teaching profession." (S4)

\subsection{Students' Views About the Definition of a Good Social Studies Teacher}

The responses about the qualities of a good social studies teacher were classified into five sub-titles. They were presented in Table -4 .

Table 4. Students' views about the definition of a good social studies teacher

\begin{tabular}{ll}
\hline Opinions & $\mathrm{f}$ \\
\hline Makes love life & 2 \\
Leaving a mark & 2 \\
Teaches life & 1 \\
Transferring & 1 \\
Has accumulation of knowledge & 1 \\
\hline
\end{tabular}

Two students who responded to the question asked about the definition of social studies teacher stated that it is the teacher who makes love life.

"After primary school, they are people who make students love life, dream, and could tell what they know instead of detaching from life. "S3

"I don't think that a person who does not love people can become a teacher." S1

Two students stated that a teacher was a person who left a mark in their life.

"It is the person who leaves a mark in students'lives. S4"

"In general, the best thing teachers do is to leave a mark. They either leave a bad mark or a good mark. There is a child who says I want to be a teacher or there might be child who says I quit school. S1"

One student who said that a teacher is a person who both transfer and knows knowledge stated, "A teacher is not only a person who knows but at the same time who can transfer. Those who cannot transfer do not become a teacher, they become a narrator. "S4

One student said that a teacher is a person who teaches life and one student highlighted that a teacher is a person who has accumulation of knowledge.

"A teacher is the person who can teach a student to lead his life." S6

"It must be a person who understands development of child psychology, knows also his own psychology and control oneself. In addition, it must be a person with an accumulation of knowledge. "S2

3.5 Students' Views Regarding the Conditions Required in Teacher Training

Regarding the question "the conditions required in teacher training" asked to the students, six categories were found. According to the responses to this question, five students determined that the courses in social studies program should be redesigned according to their functionality, four students stated that social experiments should be made, three students said that attention should be focused on applied courses, two students remarked that extracurricular activities like school trips should be included, two students said that effective teachers in every field of life should be trained, and one student said that schools for pilot(or trial) should be opened. The related titles were presented in Table-5. 
Table 5. Students' views regarding the conditions required in teacher training

\begin{tabular}{ll}
\hline Opinions & $\mathrm{f}$ \\
\hline Redesign of the courses in the program according to their functionality & 5 \\
Make social experiments & 4 \\
Focus attention on applied courses & 3 \\
Include extracurricular activities & 2 \\
Train effective teachers in every field of life & 2 \\
Open pilot schools & 1 \\
\hline
\end{tabular}

The students' views about the redesign of the courses in the program according to their functionality involve adding or extracting some courses from the program:

"Book analysis is a very simple course but a whole semester was given and it is four hours. The lecturer always keeps repeating the same things. A person who looks at the course book can make comments about the book like pictures, content, paper quality without studying this course. "(S1)

"Geographic information systems and course book analysis are two unnecessary courses. Diction course can be included in place of them." S3

"For example we had Turkish course, it is our written and oral narrative courses. A very serious rhetoric and diction courses must be included because there are many students coming from different regions and they have different accents. When they are appointed as a teacher, they cannot express themselves due to the problems like not being able to transfer knowledge, tell something or accent. " S4

"In fact, communication course or even effective communication course should be included." S6

"There are smart boards in all schools but we do not know how to use them effectively and correctly. A course like this can be included. Electronic information network and e-school systems must be taught. At least, if we have some preliminary information about them, we can implement them when we go on a training course. "S4

"We have to choose the elective courses, but I have not chosen any courses up to now." S2

The students' opinions who said that attention on social experiments must be paid were given below:

"For example, we can make social experiments. We have never made social experiments in our life and we interact with people" (S1)

"Extracurricular education can be offered like trip and observation and case study. If we cannot create the environment in the class, we will leave the school, go into the street and make the social experiment together, sir. "S6

"Thanks to the social experiments we made before; we can develop not only child's psychology in the class but also his relationship with his family or environment." S2

"What is the main responsibility of social studies? To raise a good citizen. When we have students carry out social experiments like this, we can raise people who will not betray their country, at least." S4

There are only three students who argued that practices should be paid more attention. However, considering the responses to the previous questions, it is revealed that nearly all students mentioned the lack of applied courses.

"More practice should be included" S1

"It is required to train teachers who can tell something in education faculties. More time and attention must be given for practical training." S4

"Education faculties must serve as a laboratory." S2

The students who argue that out-of school setting activities must be included defended that teaching must not be only taught in the classroom but also outside the school. They remarked that such activities always retained in their minds throughout their educational life. "Sir, we must go out of the school. For example, we can go to an orphanage where children without family live." S5

"After the school trip and observation practice last year, I told madrassa to my mother. I read about it after watching the videos. Similarly, I told my mother and made her read it. She was impressed a lot and I was impressed too because I could teach her." S6

One of the students who participated in the research argued that the teacher must be effective in every field of life and 
thus the programs in education faculties must be compatible with this.

"To me, teachers who can inform students in every field of life, not only in the department we study, must be trained by getting out of these strict rules." S6

"In short, they must motivate us to become a teacher beginning in the first year of our studies. " S5

Another participant revealed that education faculties have their own school for piloting.

"For example, there might be classes or school where children study. We can do experiments on them. Schools for piloting can be set up for education faculties and they become out laboratories." S2

\section{Discussion and Conclusion}

This study aimed at exploring the pre-service social studies' teachers view about teacher training. Thus, the pre-service teachers' opinions regarding the purposes of teacher training, whether or not education faculties succeeded in teacher training, whether or not the courses taken were effective in their teaching career, the definition of teacher, and the conditions required for teacher training were taken. In line with this purpose, data were gathered via focus group interviews and analysed.

Considering the results related to the first sub-problem, the pre-service teachers argued that the purposes of the education faculties were to graduate students or tell subjects based on memorization. In addition to these negative opinions, they emphasized that in fact the purpose of the education faculties should not be only to graduate student equipped with knowledge but also they must train people who love human beings, are not selfish, are well-equipped in every field, and are broad-minded. These results obtained from the research data show similarity to the comparative study about social studies education carried out by Tarman and Adalar (2016) in the USA and Turkey. As a result of the study, Tarman and Adalar (2016) determined that a training focusing more attention on practice was given in the USA, thus, the program in Turkey should be revised. Moreover, Tonga (2012) mentioned that well-equipped teachers must be trained in the study that evaluated social studies education undergraduate program.

The responses given to the second sub-problem that is whether or not education faculties succeeded in teacher training are generally negative. The students participating in the study evaluated the reasons for failure under three main titles. One of them is to focus attention on theoretical education in education faculties and the other one is lack of training practices, and the last one is the lack of students' personal efforts. Similar to the results of our study, Yilmaz and Altınkurt (2011) concluded that pre-service teachers did not develop themselves. Moreover, Tarman and Adalar (2016) concluded that training practices were inadequate and these practices must be carried out not only in the final year of students' studies but also in the previous grades. Tonga (2012), Tarman and Adalar (2016), Beldağ and Yaylac1 (2014), and Özer and Alkan (2017) in their studies revealed that the theoretical education was given more attention in the program.

The question whether or not the courses taken in education faculties were successful in teaching profession composed the third sub-problem of the study. The pre-service teachers' responses to this question were categorized into four titles. Out of these four categories, two of them are positive and two of them are negative. The participants who think positively about the subject stated that academic staffs' lecturing was good and existing applied courses would make contributions to their professional experience. As a result of their studies, Beldağ and Yaylacı (2014) concluded that pre-service teachers gained experience from the applied courses like training practice. In addition, Akhan (2015) concluded that there was not a problem with the teachers' lecturing but they were incompetent about how to tell the subject. Those who think negatively about this question mentioned reasons resulting from the types of examinations, lack of training practices, teaching based on memorization, and lack of applied courses. Kaymakçı (2012) in his study which examined social studies undergraduate programs concluded that $70 \%$ of the 2006 program consisted of content knowledge and general culture courses and only $30 \%$ of them involved professional knowledge for teaching.

The responses given to the question which is another sub-problem of the study and is about the definition of teacher consisted of positive opinions. According to the pre-service teachers, teachers are the people who not only have accumulation of knowledge but also make their students like and teach life, leave a mark in their lives, and transfer knowledge to their students.

The question "in your opinions, how is a teacher trained?" makes up the fifth sub-problem of the study. According to the data obtained from the focus interviews, nearly all of the pre-service teachers stated that the courses in the program should be revised considering their functionality. Akhan (2015) and Kaymakçı (2012) in their study emphasized that the courses in the program must be redesigned. According to pre-service teachers, such courses as diction, effective communication, rhetoric, and use of smart board must be included in the program. The pre-service teachers highlighted that a teacher must have knowledge in every field of life and argued that they must do social experiments in education faculties to understand children's psychology much better in their professional life. In addition to this, they mentioned 
focusing more attention on practises and stated that the training practices should be increased. Beldağ and Yaylacı (2014) and Tonga (2012) in their studies reached the similar result. According to the pre-service teachers, each education faculty must have a school for piloting. Thus, they highlighted that successful implementations could be carried out by the pre-service teachers in these schools. Tarman and Adalar (2016) determined that education faculties must have schools for piloting just like the professional development schools or laboratory schools in the USA. The pre-service teachers who stated that extra-curricular activities should be included stated that by using trip and observation methods, visits could be organized to historical buildings, museums, elderly and child care centres. Considering the similar studies, the importance of using historical artefacts, museums, and immediate environment in education was highlighted (Aytaç (2014); Çetin, Kuş and Karatekin (2010); Malkoç \& Kaya (2015).

According to the results obtained from the data, some recommendations should be made. One of them is to focus more attention on applied courses because most of the students participating in the study think that they will not be able to implement what they have learnt in the faculty after their graduation in the schools they teach. Thus, some revisions are required for some courses in the application-oriented program. For example, it is required that some courses such as diction, rhetoric, or effective communication should be included in the program. Moreover, extra-curricular activities should be done. It is required that pre-service teachers should not be only trained in their own field but also well-equipped teachers should be trained to help people in their environment.

\section{References}

Akar, H. (2016). Case Study. In Saban, A. \& Ersoy, A. (Eds.). Qualitative research designs in education. Ankara, Anı.

Akhan, N. E. (2015). Views of social studies teacher candidates on social studies undergraduate program. International Journal of Social Science, 32(3), 267-289. https://doi.org/10.9761/JASSS2735

Akyüz, Y. (2001). History of Turkish education ( $8^{\text {th }}$ ed.). İstanbul, Alfa Basın Publishing

Aytaç, A. (2014). The place and importance of the field trip method for the social science teacher candidates education. Journal of Hasan Ali Yücel Education Faculty, 11-1(21), 55-69.

Beldağ, A., \& Yaylacı, A. F. (2014). Candidate social studies teacher' views on Turkish education system. Electronic Journal of Social Sciences, 13(48), 90-107.

Bilgili, A. S. (2013). Principles of social studies. In A. S. Bilgili (Edt.). Social sciences and social studies from past to present. pp. 2-35. Ankara, Pegem.

Binbaşığlu, C. (2009). History of Turkish education from the beginning to the present. Ankara, Anı.

Bowling, A. (2002). Research methods in health: investigating health and services. Philedelphia, PA: McGrow-Hillhouse.

Boy, A. (2017) A short history of madrasahs and madrasahs in Kayseri. Adnan Menderes University Journal of Social Sciences Institute, 4(1), 57-73. https://doi.org/10.30803/adusobed.309070

Çetin, T., Kuş, Z., \& Karatekin, K. (2010). Opinions of class and social sciences teachers about trip-observation method. Social Sciences Research Journal, 2, 158-180.

Çokluk, Ö., Yılmaz, K., \& Oğuz, E. (2011). A qualitative interview method: focus group interview. Journal of Theoretical Educational Science, 4(1), 95-107.

Dilshad, M. R., \& Latif, I. M. (2013). Focus group interview as a tool for qualitative research: an analysis. Pakistan Journal of Social Sciences (PJSS), 33(1), 191-198.

Doğan, İ. (2010). Outlines of the history of Turkish education: institutions, individuals and discourses. Ankara. Nobel Yayın Dağıtım.

Ergün, M. (1982). Turkish education in Atatürk period. Ankara, Ankara University.

Kaymakçı, S. (2012). Evaluation as content of social studies undergraduate programs. International Social Science Education of Journal, 2(1), 41-57.

Kılıç, A., \& Saruhan, H. (2006). Teaching skills of technical education faculty teacher candidates. Selçuk University Journal of Social Sciences Institute, 16, 407-417.

Malkoç, S., \& Kaya, E. (2015). The usage of non-classroom environments in social studies education. Elementary Education Online. 14(3), 1079-1095. https://doi.org/10.17051/io.2015.40410

Öcal A., \& Yakar, H. (2015). Global awareness education in 1968-2005 social studies curriculums. Abant İzzet Baysal University Journal of Faculty of Education. 15(I), 307-327. 
Öztürk, C. (2007). Teacher training policy in Atatürk period. Ankara. Turkish History Association.

Öztürk, C. (2009). Social studies: an interdisciplinary approach to social life, In Öztürk, C. (Edt). Teaching social studies: democratic citizenship education. pp. 1-31. Ankara, Pegem.

Safran, M. (2011). Overview of social studies teaching. In Tay, B., \& Öcal, A. (Eds). Teaching social studies with special teaching methods, pp. 2-16. Ankara, Pegem.

Sakaoğlu, N. (2003). History of education from Ottoman to today. İstanbul, İstanbul Bilgi University Publishing.

Şimşek, H., \& Yıldırım, A. (2013). Qualitative research methods in the social sciences. Ankara, Seçkin Publishing

Tarman, B., \& Adalar, H. (2016). Comparıson of the social studies education teacher training programs of United States and Turkey: Pace and Gazi Unıversity social studies teaching program examples. Abant Izzet Baysal University Journal of Faculty of Education, 16(2), 1603-1630.

Tay, B. (2011). Status of social studies teaching, present and future. In R. Turan, \& K. Ulusoy (eds.), Principles of Social Studies (pp. 2-16). Ankara, Pegem.

Tonga, D. (2012). The evaluation of social studies teaching undergraduate program. The Journal of Turkish Educational Sciences, 10(4), 780-803.

\section{Copyrights}

Copyright for this article is retained by the author(s), with first publication rights granted to the journal.

This is an open-access article distributed under the terms and conditions of the Creative Commons Attribution license which permits unrestricted use, distribution, and reproduction in any medium, provided the original work is properly cited. 